\title{
The Effect of Interactive Education on Anxiety in Parents of Hospitalized Children in Waikabubak
}

\section{Uly Agustine* and Grasiana Florida Boa}

Department of Nursing, Poltekkes Kemenkes Kupang, Indonesia

\section{ORCID}

Uly Agustine: https://orcid.org/0000-0003-2879-5733

Abstract. According to the World Health Organization, in $2015-2017,15 \%$ of child deaths were due to pneumonia, and each year, diarrhoea causes around 760,000 deaths in children under five years. The neonatal morbidity and mortality rates in West Java are 19/1000 live births and 32/1000 births under five, respectively. Hospitalization of children can cause anxiety in parents. This anxiety can be due to various factors and can be an obstacle in providing nursing interventions. This study aimed to determine the effect of the KIE intervention (Communication, Information, and Education) on

Corresponding Author: Uly Agustine; email: agustineuly@gmail.com

Published: 7 February 2022

Publishing services provided by Knowledge E

(c) Uly Agustine and Grasiana Florida Boa. This article is distributed under the terms of the Creative Commons.

Attribution License, which permits unrestricted use and redistribution provided that the original author and source are credited.

Selection and Peer-review unde the responsibility of the IVCN Conference Committee.
G OPEN ACCESS the level of anxiety of parents with hospitalized children in the Children's Room of Waikabubak Hospital. This study used an analytical experimental approach. The p-value obtained was $<0.01$, which means there was a significant difference in the level of parental anxiety after being given $\mathrm{KIE}$, and therefore that this intervention was effective in reducing the level of anxiety of parents with hospitalized children at Waikabubak Hospital.

Keywords: KIE, anxiety level

\section{Introduction}

Information and education provided to parents are carried out through communication that is carried out starting from the first day of hospitalization until the last day of hospitalization. So the role of health workers in KIE is very necessary. The purpose of KIE is to add information to clients, parents, and families, which is expected to reduce parental anxiety and not hinder the provision of services needed when children are hospitalized. KIE is a combination of 3 concepts, namely Communication, Information, and Education. These three concepts are related to one another, according to [1] There is no supporting data regarding the percentage of events and causes of parents experiencing anxiety. The effectiveness of the KIE administration program has not yet been confirmed to reduce the anxiety level of the client's parents in Waikabubak Hospital because research related to the effectiveness of KIE administration on anxiety levels has never been done in this hospital. Only a few parents claimed to be satisfied if they were given all information about hospitalized children at Waikabubak Hospital. 


\section{Methods}

\subsection{Design}

This research uses the descriptive analytical method. The researcher uses the Experiment approach to analyze the dynamics of the correlation between phenomena or between risk factors and effect factors. This research was conducted from January 12, 2019, to January 19, 2019. The research location was in the Children's Room of the Waikabubak Hospital. The address is at Jl. Adhayaksa KM 3, Soba Wawi, Loli, West Sumba Regency, East Nusa Tenggara.

\subsection{Sample}

Part or representative of the population used as research subjects. In this study, the sampling technique used was the total sampling technique and inclusion criteria. The sample size obtained during the study was 20 people.

\subsection{Procedure}

The population in this study were all parents with children hospitalized in the Children's Room at the Waikabubak Hospital who met the inclusion criteria. Part or representative of the population used as research subjects. In this research, the sampling technique used is the Total Sampling technique. Namely, all populations are used as samples to be studied. Because the population is unknown during the study. Then the sample is taken based on the inclusion criteria using total sampling.

\subsection{Questionnaire for Data Collection}

The measurement tool uses a questionnaire. Research ethics or data collection in this study include informed consent, anonymity (without a name), Confidentiality (confidentiality), Self-determination, and justice.

\subsection{Data Analysis}

Data analysis was performed using two analytical methods, namely univariate and bivariate analysis. After the data is rated and entered (entry), the data is then analyzed using SPSS. 
TABLE 1: Anxiety Levels Before KIE in Parents with Children Hospitalized at Waikabubak Hospital

\begin{tabular}{l|l|l|l|} 
Number & Anxiety level & $\mathrm{n}$ & $\%$ \\
1 & Mild anxiety & 1 & 5.0 \\
\hline 2 & Moderate anxiety & 3 & 15.0 \\
3 & Anxious & 14 & 70.0 \\
4 & Panic & 2 & 10.0 \\
& Total & 20 & 100
\end{tabular}

TABLE 2: Anxiety Levels After KIE in Parents with Hospitalized Children at Waikabubak Hospital

\begin{tabular}{l|l|l|l|} 
Number & Anxiety level & Frequency & Percent \\
\hline 1 & Mild anxiety & 9 & 45.0 \\
\hline 2 & Moderate anxiety & 8 & 40.0 \\
3 & Anxious & 2 & 10.0 \\
\hline 4 & Panic & 1 & 5.0 \\
& Total & 20 & 100
\end{tabular}

\section{Results}

After doing research based on univariate and bivariate analysis, the univariate analysis explains the characteristics of the research sample data, where the respondent's answer categories are displayed in the form of a frequency distribution table for each variable. At the same time, the bivariate analysis section will explain the influence between the two variables with the paired T-test.

\subsection{Univariate Analysis}

Based on table 1, the results showed that the range of anxiety levels before KIE in parents with children hospitalized at Waikabubak Hospital was 5\% mild anxiety, 15\% moderate anxiety, $70 \%$ severe anxiety, and 10\% panicked.

Based on table 2. the results of the range of anxiety levels after KIE in $45 \%$ of parents with children treated at Waikabubak Hospital are not anxious, $40 \%$ are mildly anxious, $10 \%$ are moderately anxious, and $5 \%$ are severe anxiety.

\subsection{Bivariate Analysis}

Based on table 3 of the 20 respondents before and after KIE in measuring anxiety, the average value (mean) of decreasing the level of anxiety was 2,100 . The results of 
TABLE 3: Differences in Anxiety Levels before KIE and after KIE in Parents and Children Hospitalized at Waikabubak Hospital

\begin{tabular}{|l|l|l|l|l|} 
Number & Variable & Mean & Df & P. value \\
\hline 1 & Before KIE & 3,85 & 19 & 0.000 \\
\hline 2 & After KIE & 1,75 & & \\
\hline
\end{tabular}

hypothesis testing using the Paired-sample T-test with a statistical test obtained a pvalue of 0.000 . The $p$-value of 0.000 , which is smaller than 0.05 , means that there is a significant difference in the level of anxiety of parents before and after being given KIE.

\section{Discussion}

\subsection{Levels before KIE on Parents with Children hospitalized at Waikabubak Hospital.}

Based on table 1, the results showed that the range of anxiety levels on KIE in parents with children hospitalized at Waikabubak Hospital was 5\% mild anxiety, 15\% moderate, $70 \%$ severe anxiety, and $10 \%$ panicked. It can be said that parents with hospital children experience anxiety with different levels of anxiety. They range from moderate anxiety to panic. These results strengthen the yen research that previous researchers have done.

\subsection{The level of anxiety after KIE in parents with children hospital- ized at Waikabubak Hospital}

In table 2, it is found that there is a difference in the old anxiety level scores before and before being given KIE. The results of this study strengthen that carried out by [2] with the title The Relationship of Nurse Therapeutic Communication with Anxiety Levels of Patients' Families Treated in the Huu Room of Rsu Sele Be Solu, Sorong City. In his research, it was found that $p$-value $=0.001=0.05$, then Ho was rejected, so that there was a relationship between nurse therapeutic communication with the level of a family treated in the HCU room at Sele Be Solu General Hospital, Sorong City.

\subsection{Differences in Anxiety Levels before and before KIE in Parents and Children Hospitalization at Waikabubak Hospital}

The researcher analyzed the anxiety level scores in table 3 . The average score of the anxiety level before KIE was 3.85, with a standard deviation of 0.671. The average score after anxiety after KIE was given was 1.75 , with a standard deviation after KIE was 
0.851. The average decrease in the level of anxiety in the respondents was 2,100 . The initiative decreased anxiety scores before and before being given KIE. From the results of hypothesis testing using the Paired sample T-test, the $p$-value is $0.000(p<0,05) P$ value 0.000 , which is smaller than 0.05 , which means that there is a significant difference in the level of parental anxiety after being given KIE. It means there is a different anxiety level and in parents with hospitalized children at Wakaibubak Hospital. I was assuming that the level of anxiety decreased in the elderly.

There are differences in the level of anxiety before presenting KIE to parents and children hospitalized at Waikabubak Hospital-assuming that there is a decrease in the level of anxiety in parents with hospitalization of children at Waikabubak Hospital. The $p$-value is $0.000(p<0.01)$, which means there is a significant difference in the level of parental anxiety after KIE.

\section{References}

[1] Effendy N. Fundamentals of public health nursing. $2^{\text {nd }}$ ed. Jakarta: EGC; 1998.

[2] França JRF de S, Costa SFG da, Lopes MEL, et al. The importance of communication in pediatric oncology palliative care: Focus on Humanistic Nursing Theory. Revista latino-americana de enfermagem. 2013;21:780-786. 